Volume 1 Number 2 (2021): 30-37

\title{
Practical Leadership: Learning from Great Rulers in History
}

\author{
Jennifer H. Operio, LPT, DBA
}

School of Business and Accountancy, Holy Angel University, Philippines

\begin{abstract}
This paper examines the applied principles and leadership styles of great ancient men in the light of the Bible as the Word of God. Practically speaking, scholarly literature in leadership and management lacked attention to the study of biblical figures as leaders. The author utilised secondary analysis of qualitative information from documented life stories of renowned leaders in human history. This paper utilizes qualitative content analysis to evaluate patterns of popular ancient leaders' styles in leading their subjects. With content analysis, the author is obliged to read and re-read the text, specifically the Bible, as the main source of data and focus on the specific timeline of the ancient world. The scope and limitation of this paper cover only the discussion on the prominent historical people, specifically Biblical characters, and does not include the current leaders of our time. This paper hopes to bring back the basics on leading people worth emulating by modern-day leaders. It explores the successes and failures of these ancient leaders that shaped history and even world cultures. It also aims to promote a blueprint that was already utilised by leaders in the ancient world regarding leading constituents and subjects. The scope and limitation of this study enfold the discussion on the prominent historical people and does not include the current leaders of our modern time.
\end{abstract}

Keywords: ancient; history; values; character

This is an open access article under the CC-BY-NC license.

\section{INTRODUCTION}

Practical leadership is a concept which applies the word "practical" as a guide to help us become better leaders (Arizala, 2010). The word "practical" connotes being concerned with ordinary things that can be adapted or designed for actual utilization ("practical", n.d.). So, if we put all things together, it is a kind of leadership that anyone can practice. With this idea in mind, the author thought of studying the ancient leaders from the Bible, learning from them, and coming up with a proposed model that modern-day leaders can integrate into their current leadership styles and strategies. In our modern-day, there is what we call a leadership crisis. In the year 2014, as per a study in the World Economic Forum, there was great concern about the lack of values in leadership. The younger generation is so concerned about the kind of values being displayed by the world and corporate leaders. It is so sad to note that most companies are doing everything to ensure cost-cutting in the form of not raising the minimum wage. However, these same companies provide greater compensation and luxuries for executives (World Economic Forum, 2014).

In the own perception of Nocera (2012), organizations that seek to improve society rather than just to earn profits follow moral capitalism. According to Hjelmgaard, there is another kind of capitalism, in which firms are just thinking about profits and taking advantage of others, and that includes clients and customers. Hjelmgaard continued that; it is also very alarming to note the

Corresponding author

Jennifer H. Operio, LPT, DBA, joperio@hau.edu.ph

DOI: https://doi.org/10.31098/jsetp.v1i2.731

Research Synergy Foundation 
increase in income inequality where only the top one percent of society will soon consume fifty percent of the world's wealth (Hjelmgaard, 2015).

In this paper, the ancient leadership values were figured out and analyzed on the premise that they can be used to restore the ideal of leadership. Lives of ancient leaders and how they managed their constituents and wealth, which were written in one of the most well-read and bought books of all times - the Bible, were explored by the author to understand why despite their shortcomings and imperfections, they were able to become great leaders who even changed cultures and history of mankind.

Religions with monotheistic beliefs, such as Judaism, Christianity, and Islam, were slightly touched in this paper. The writer of Islamic history and civilization states that: "equality, justice, compassion, freedom of consciousness and human rights and dignity are stressed out by these religions" (Ali, 2011). However, scrutinizing the beliefs and dogmas of these three major religions was not the scope of this study. The aforementioned religions all have their origin from the Middle East and recognize Abraham as their first prophet and father of their faith. One of the author's subjects of investigation is Abraham's life and leadership practice as the patriarch of his culture and nation.

Graft and corruption are committed by leaders on a global scale. In this paper, one can realize that even ancient leaders were bound to commit human errors and mistakes (Friedman and Friedman, 2018). It is the greatest inspiration of the author to cite that the main source of her document content analysis is the Bible - as the most popular book of all time and the infallible truth. It is also the most translated and most frequently purchased book in the world (Open Education Database, n.d.).

The goal of this study is to look for an answer to the central question: What can we learn from the practices of ancient leaders in history? and to the following sub-questions:

1. How did the ancient leaders overcome their shortcomings and imperfections?

2. How absolutely necessary is morality in leadership?

3. What makes a good and bad leader?

4. Is social leadership a thing in the past, or is it applicable today?

\section{LITERATURE REVIEW}

There are many written studies and write-ups in the field of leadership. But there is a shortage of studies encouraging practical methods that lead to becoming a better and more resilient leader. The goal of this literature review is to compare the past and most recent studies and articles about the rise and fall of leaders, organizations or business firms, kingdoms, and cultures due to the death of good governance. In our present time, many issues emerged regarding dishonesty, fraud, and placing priority on personal motivation with self-serving interest. Rabbi Lord Jonathan Sacks (2009) mentioned that social justice is a term that was coined from the Hebrew word, "tzedakah", meaning distributive justice and equity. Its importance is understood by all countries that follow the tradition set by Abraham, the Iraqi ancestor of the Jews and the Arabs. Equal opportunity for all should be the priority of those who are in power and who have wealth. It is interesting to note that a society that is not following the tradition set by Abraham favors the rich and powerful and income inequality. We can learn much about the leadership of Joseph the dreamer. The series of events in Joseph's life is summarized in the book of Genesis (chapters 37-50). Another excellent and 
astounding leader in the person of Moses. In the last forty years of his life, he grew to become one of the greatest if not the greatest leader who ever lived and walked on earth. He led the approximately 2.5 million Jews from slavery in Egypt towards the Promised Land. David, from being a shepherd boy to becoming the most well-loved king of Israel. David's humility was remarkable and helped him fulfilled God's purpose in his generation. Ancient leaders were not exempted from committing grave mistakes. King Saul, for example, started right and with humility. But towards his latter days, he became so greedy in his position and disobeyed God because of his arrogance.

The book of Proverbs provides a great lesson about leadership. Wisdom refers to the virtuous life on justice and righteousness. It mentioned that the beginning of wisdom is "fear of the Lord". According to Kugel (2007), a wise person is someone who treads the path of wisdom, learning its simple lesson of following the straight and narrow and seeking to live life in accordance with it. In contrast, the fool may actually be a diabolical genius, but by having rejected wisdom's lessons from his own life, he has allied himself with anti-wisdom, immoral excess, and all of the human vice. The book also emphasized that the vision of a leader provides guidance for the people, but the vision has to be based on ethics, spirituality, and righteous life.

This study tackles the life stories of ancient leaders in the light of the Bible, which will make us understand that they were also epitomes of human frailties and flaws. But it is also interesting to note that they thrived as good leaders who changed the course of world history and the trajectory of their nation's fate. Ancona et al., 2019 mentioned that society always has high expectations from executives and leaders. But being imperfect, no person can live up to the highest standards. The myth of a complete leader has to end. It is interesting to note that the case of Enron (2021) forced AICPAs (American Institute of Certified Public Accountants) to engage in significant damage control (Thomas, 2002). As a result, the Sarbanes-Oxley Act of 2002 was enacted as a comprehensive reform of business financial practices (Carlson, 2019). It is a US federal law that was passed to respond to a number of corporate financial reporting scandals. The issue of lack of values in leadership is a factor why in our modern-day, we encounter problems in either corporate governance or political management (World Economic Forum, 2014). According to Deakin and Konzelmann (2011), the act of Sarbanes-Oxley Law of 2002 is like a mirror-image of Enron, which needed a point-for-point act against corporate governance failures. Likewise, in order to contribute to solutions against business scandals, this study probed to look into the basic aspect that a leader must possess.

In his paper, Van Wart (2014) discussed that virtuous leadership is also tantamount to responsible and ethical leadership. Additionally, the study by Rivera and Karlsson (2017), building a culture of integrity which means putting in place governance structures effectively and including processes and control mechanisms that discourage wrongdoing, are the best ways to prevent lapses and instant scandal in the corporate world. In this paper, the author tried to reconcile the resiliency and improved leadership to deeply rooted integrity and character formation of the ancient leaders. The author made a content analysis of the life stories of each ancient leader mentioned in this paper. It is similar to what other authors recognized, such as personal stories and their power, including narratives, are getting attention which is becoming popular in the business world (Gallo, 2016; Howard, 2016; Prive, 2016). Based on the exemplified presentation of the ancient leaders, we can deduce that a leader should be transformational with values like Abraham. A successful leader is 
compassionate and loves humankind, humble, not envious of others, and welcomes the stranger and the needy.

To summarize the key findings taken from the listed literature and studies, in general, society has a high standard and expectations from corporate leaders though it is an established fact that humans are imperfect creations. Misreporting specifically of the financial status led to several sorts of scandals and legal procedures against corporate officials. Virtues and moral values are essentials towards better and successful leadership. Finally, the business world is starting to focus its attention on the power of personal stories and their narratives. The significance of the findings of the above-related studies and literature to the current study is that those findings pointed to understanding how the ancient leaders resolved their imperfections and shortcomings prior to the creation of modern federal laws or being educated under a very popular leadership "guru". This study attempted to discover the former practices of ancient leaders and what we can learn from them that we may apply to our present time.

\section{RESEARCH METHOD}

This paper utilized the qualitative content analysis to evaluate patterns of popular ancient leaders' styles in leading their subjects. Luo (2021) discussed that content analysis is a method in research, and to be able to conduct it, an author can collect data from sets of texts which can be written, oral or visual. Some examples of these are books, magazines, interviews, photographs, social media posts, etc.

This paper focused on qualitative content analysis - that is, understanding and interpreting the data gathered from the number one source: the Bible. With content analysis of secondary data and documentation, the author is obliged to read and re-read texts, specifically the Bible, as one of the sources of data and focus on the specific timeline of the ancient world. The Bible has 66 books - 39 books in the Old Testament; from Genesis to Malachi and 27 books of the New Testament; from the book of Matthew to Revelation. Primarily the author read, re-read, and continually re-reading it more than 10 times at this point in time to gain a deeper understanding of the leadership practices of selected kings, leaders, and patriarchs in ancient times. By investigating the successes and failures of these leaders, this research makes a drawn conclusion which is set at the last part of the paper.

\section{FINDINGS AND DISCUSSION}

The major task of writing about practical leadership and what we can learn from ancient leaders is to make contextually grounded points that will become a contribution in the field of leadership. This study shows that equality, social justice, and human dignity are best kept in mind by leaders who believe that mankind is created in the image of God. A good leader is fair and loves justice. This is similar to that of a former study by Schroeder et al. (2019) on a four values framework that includes fairness, respect, care, and being honest. Through each story on the life of ancient leaders, the author found out that anyone is not exempted from offenses even as a leader. Ancient leaders who were resilient and successful were able to overlook offenses, be forgiving, and not personally take into account everything that slighted them. Humility and servant attitude are also vital, as in the example of David's life. In the midst of life crises resulting from his very own imperfections and mistakes, he humbled himself before God and begged for forgiveness. A true 
virtue that can be adopted by political leaders and public officials in countries of the world. Also, compassion should be the first motivation to lead and not to oppress or take revenge. A similar study by Okpala and Caldwell (2019) mentioned that humility, forgiveness, and love are the heart of ethical stewardship. Paul, the apostle to the Gentiles, acknowledged that he is what he is because of the grace of God (I Corinthians 15:10, NIV). He mentioned learning authentic humility through his years of being a person, a Jew first, then a minister of the Gospel. Humility, as described in the Bible, is the position and posture of the heart. According to Dr. Robert Jeffress (2020), a humble spirit is being willing to credit others for successes. Another characteristic of authentic humility is genuine interest in other people. The world today is seeing people as opportunities to use to help you get where you want to go. But the best example of this is the "servant-leader".

The Bible emphasized that God resists the proud and gives grace to the humble. True humility is the kind of attitude that finds grace before God's face. Throughout the lives of ancient men, it has been noted that people with a proud attitude never hear God speaking to them. One very interesting story in the Old Testament was in the book of Daniel. The whole chapter 4 of the Book, Daniel presented the summary of how King Nebuchadnezzar of the great kingdom Babylon recognized and acknowledged that even he is subject to the Almighty God. In the Bible, he is known as the most powerful and longest-reigning ruler of the Babylonian Empire, which ranges from BC 605-562. In world history, he is known as Nebuchadnezzar II, also known as the greatest king of the Chaldeans dynasty of Babylonia, who made it into a beautiful city. It is amazing that prior to his acknowledgment of the ultimate power of God as the Supreme Being, he was so arrogant about his achievements. For seven years, he was humbled by God; he lost his sanity, lived like a wild animal, and ate grass until such time that he admitted that God is above everyone on earth.

Anyone may not think God had anything to do with his success until one day; he realizes God had everything to do with his success. Interestingly, after his first dream, Nebuchadnezzar respects God's wisdom. After the furnace event, Nebuchadnezzar respects God's protection. Finally, after his period of madness and loss of title and humanity, he respects God's power.

The best example of what it takes to be a great leader is Joshua. He is an example of being a man of humility. Before becoming a leader, he was willing to serve. He served under Moses for forty years in the wilderness. He was Moses' assistant and servant. His servant attitude prepared him to lead after Moses' death. Great leaders do not let position or praise get to their heads. Great leaders realize they cannot place their faith in men, which includes themselves, but they must look to God.

Thinking back on the night of the Passover meal, Jesus washed his disciple's feet, including that of his would-be betrayer, Judas Iscariot. This is the greatest example of an act of humility ever done in history. Therefore, Christ set the bar for humility. God's grace is like water which flows downhill and seeks the lowest level. It never reaches the high and lofty places, but only to those who are low, meek, and humble. Humility means a person has a teachable heart and spirit. It is removing pride and arrogance from our self. It is the same as understanding our fallen nature, which causes us to think that we are a lot better than what we truly are.

An article written in Management Research Review Journal by Hendriks et al. (2020) indicated that there are five individual core leader virtues which are: prudence, temperance, justice, courage, and humanity, which positively influence work-related being. The current study revealed that intelligence and wisdom without character might make a great leader looks like a fool. Secondly, courage and firmness of decision is another innate character that a good leader must possess. 


\section{CONCLUSION \& FURTHER RESEARCH}

The following conclusions are drawn to answer the central research question: "What can we learn from the practices of ancient leaders in history?" Their exemplified life teaches us the following: (1) A leader should be transformational with values just like Abraham as mentioned by Friedman \& Langbert (2000); (2) Educating the succeeding generation of leaders should always include molding the strength of character; (3) A successful leader is compassionate and loves humankind, humble, not envious of others and welcome the stranger and the needy; (4) The focus of leadership is not to oneself but to the welfare, benefit and the good of the majority.

It has been said that "the problem of the heart is the heart of the problem". This adage reminds us that CEOs and national leaders, no matter how intelligent they are, will always shrink down to nullity when their heart is not right and free from greed or self-aggrandizement. Throughout this study, it is imperative to note that ancient leaders were not complete and perfect, yet they overcame these weaknesses by the higher virtue of humility and admitting their mistakes in handling matters. This provides us answer to the first sub-question. For the second sub-question, the morality and virtuous life of justice and righteousness lead to successful leadership and therefore is absolutely necessary. Further, anyone can be a diabolical genius without acknowledging that the source of wisdom, skills, strengths, power, authority, and success is God. It is also very important that a national leader must surround himself with counsels who have the "fear of God". Vision provides guidance to the people, and it should be based on ethical standards. People respect leaders with integrity and willingly support them. A good leader also ensures that all weights and measures are honest. The aforementioned statements led us to the answers for the third sub-question. Finally, social leadership began since time immemorial. It is a position of authority that is being given to anyone by the community out of trust and reputation earned over time. Ancient leaders were also social leaders, and anyone can become a social leader by just leading a team or group of people.

A further study is recommended that will be focusing on the successes and failures of modern-day leaders and heads of states and comparing the principles learned from this paper to the current trend in leadership. It is also suggested that social leadership be tackled further and in consonance with sustainability leadership. Another very interesting topic for future research is the significant relationship between longer-tenured CEOs and other national leaders. Humility is a trait of leaders is not popularly taken as a topic in leadership. Anyone might as well plunge into this new trajectory in leadership researches.

\section{REFERENCES}

Ali, M. D. Y. (2011). The three Abrahamic faiths and their roles in making peace, unity, and co-existence. World Journal of Islamic History and Civilization, 1(3), 187-200.

Arizala, Scott (2010). Practical leadership: what we can learn from simon says, show and tell and sharks.

American Camp Association Camping Magazine. Retrieved from: https://www.acacamps.org/resource-library/camping-magazine/practical-leadership-what-wecan- learn-simon-says-show-tell-sharks 
Ancona, D., Malone, T., Orlikowski, W. and Senge, P. (2007) 'In Praise of the Incomplete Leader', Harvard

Business Review, vol. 85, no. 2, pp. 92-100 [Online]. Available at https://hbr.org/ 2007/ 02/ in-praise-of-the-incomplete-leader (Accessed 17 April 2019).

Carlson, Rosemary. (2019). The enron scandal that prompted the Sarbanes-oxley act. Retrieved from: https://www.thebalancesmb.com/sarbanes-oxley-act-and-the-enron-scandal393497

Deakin, S. \& Konzelmann, S.J. 20 September 2011). Learning from enron. Cambridge Centre for Business Research Working Paper No. 274.

ESRC Centre for Business Research. Learning From Enron. p.3 (Accessed 23 February 2020).

Friedman, H. H. and Friedman, L.W. (July, 2018). Even great leaders make mistakes: Learning

leadership From Moses. Retrieved from:

https://www.researchgate.net/publication/312234490_Even_Great_Leaders_Make_Mistakes_Lea rning_Leadership_from_Moses

Friedman, H.H. \& Fireworker, R.B.(2019). Learning leadership from trump: what not to do. Journal of Leadership, Accountability and Ethics. 16(3), 21-33

Friedman, H. H.(2010, October 25). Return to sodom and gomorrah: The 'new' politicaleconomic system. Available at SSRN :http://ssrn.com/abstract=1697822 or http://dx.doi.org/10.2139/ssrn.1697822

Friedman, H. H. and Friedman, L.W. (2004). Biblical leadership: Insights for today's managers. Electronic Journal of Business Ethics an Organization Studies. Retrieved From http://ejbo.jyu.fi/

Friedman, Hershey H. and Mitchell Langbert. (2000). "Abraham as a transformational leader." The Journal of Leadership Studies, Vol. 7, No. 2, 88-95.

Gallo, C. (2016). The storyteller's secret. New York: St. Martin's Press.

Grant, A. (2013). Give and take: A revolutionary approach to success. New York: Viking.

Greenleaf, Robert K. (1983). Servant leadership: A journey into the nature of legitimate power and greatness. Mahwah, NJ: Paulist Press.

Hjelmgaard, K. (2015, January 20). By 2016, 1\% will have 50\% of total global wealth. USA Today. 1B.

Hertz, Joseph H. (1992). The pentateuch and haftorahs. London: Soncino Press.

Howard, B. (2016, April 4). Storytelling: The new strategic imperative of business. Forbes. Retrieved from http://www.forbes.com/sites/billeehoward/2016/04/04/storytelling-the-newstrategic-imperative-of-business/2/\#59fc0f7c224a

Huberts, L. W. J. C. (July 18, 2018). Integrity: What is it and why it is important. International on Ethical Leadership: Past, Present, and Future of Ethics Research, Vol. 20, 18-32. https://doi.org/10.1080/10999922.2018.1477404

Kugel, J. L. (2007). How to read the Bible. New York: Free Press.

Jeffress, Dr. Robert. (2020). Characteristics of genuine humility. The Lockman Foundation.

Luo, Amy. (2021). What is content analysis and how can you use it in your research? Retrieved from: https://www.scribbr.com/methodology/content-analysis/

Nocera, J. (2012, March 17). The good, bad and ugly of capitalism. New York Times, A21. 
Okpala, C., and Caldwell, C. (2019). Humility, forgiveness and love - the heart of ethical stewardship. The Journal of Values-Based Leadership. Vol. 12. Retrieved from: https://scholar.valpo.edu/cgi/viewcontent.cgi?article=1281\&context=jvbl

Open Education Database n.d., The 50 most influential book of all time. Retrieved from: https://oedb.org/ilibrarian/50_books_that_changed_the_world/

Prive, T. (2016). The most common practices of super-achievers. Forbes. Retrieved from http://www3.forbes.com/entrepreneurs/the-most-common-practices-of-super-achievers/

Rivera, K., and Karlsson, P. (2017, June 6). CEOs are getting fired for ethical lapses more than they used to. Harvard Business Review. Retrieved from: https://hbr.org/2017/06/ceos-aregetting-fired-for-ethical-lapses-more-than-they-used-to [Google Scholar]

Sacks, Jonathan. (2009). The way of tzedakah: love as justice. The Rohr Jewish Learning Institute. Retrieved from: https://lessons.myjli.com/gifts/index.php/lesson-1/the-way-oftzedakah-love-as-justice/

Schroeder, Doris, et.al. (2019). The four values frameworks: fairness, respect, care and honesty. Equitable Research Partnerships pp.13-26. Retrieved from: https://link.springer.com/chapter/10.1007/978-3-030-15745-6_3

The New King James Version Bible. Thomas Nelson Publishers.

The New Internationa Version Bible.

Thomas, C. William. (2002). The rise and fall of Enron: When a company looks too good to be true, it usually is. Journal of Accountancy. Retrieved from: https://www.journalofaccountancy.com/issues/2002/apr/theriseandfallofenron.html

Van Wart, M. (2014). Contemporary varieties of ethical leadership in organizations. International Journal of Business Administration, 5(5), 27. doi:10.5430/ijba.v5n5p27 [Crossref], [Google Scholar]

World Economic Forum (2014). Top 10 trends of 2014: A lack of values in leadership. WEForum.org. Retrieved from http://reports.weforum.org/outlook-14/top-ten-trends-categorypage/7-a-lack-of-values-in-leadership/ 